\title{
Pengaruh Gaya Kepemimpinan Transformasional Dan Kompensasi Finansial Terhadap Kinerja Karyawan PT. Traya Tirta Cisadane
}

\author{
${ }^{1}$ Estika Paramita Sani, ${ }^{2}$ Yolla Komala, ${ }^{3}$ Feymi Damayanti ${ }^{4}$ Deny Hadi Saputra \\ ${ }^{1-4}$ Fakultas Ekonomi, Universitas Matana, Tangerang
}

Article history

Received:04-Mei- 2021

Revised: 12-Juni-2021

Accepted:08-July-2021

*Corresponding Author:

Estika Paramita Sani,

Yolla Komala,

Feymi Damayanti,

Deny Hadi Saputra

Fakultas Ekonomi,

Universitas Matana,

Tangerang

Email:

estika.paramita@mataunive

rsity.ac.id

\begin{abstract}
Abstrak: Persaingan dunia usaha sangatlah ketat, hal ini menjadikan tantangan bagi dunia usaha dan setiap komponen yang terlibat mampu memaksimalkan potensi yang dimilikinya. Tujuan penelitian ini adalah untuk mengetahui apakah gaya kepemimpinan transformasional dan kompensasi finansial berpengaruh langsung terhadap kinerja karyawan, apakah kinerja karyawan dapat memediasi pengaruh gaya kepemimpinan transformasional dan kompensasi terhadap kinerja karyawan perusahaan pengelola air mineral pada PT Traya Titrta Cisadane. Penelitian ini menggunakan metode penelitian kualitatif. Teknik pengumpulan data yang digunakan adalah analisis jalur. Data dikumpulkan dengan menggunakan kuesioner yang disebarkan. Hasil penelitian ini adalah kepemimpinan transformasional berpengaruh positif secara langsung terhadap kinerja karyawan. Kompensasi berpengaruh positif secara langsung terhadap kinerja karyawan.
\end{abstract}

Kata Kunci : Kinerja Karyawan, Kompensasi dan Gaya Kepemimpinan Transformasional.

\section{PENDAHULUAN}

Perubahan lingkungan yang begitu cepat menuntut kemampuan mereka dalam menangkap fenomena perubahan tersebut, menganalisis dampaknya terhadap organisasi dan menyiapkan langkah langkah guna menghadapi kondisi tersebut., peran manajemen sumber daya manusia dalam organisasi tidak hanya sekedar administrative, tetapi justru lebih mengarah pada bagaimana mampu mengembangkan potensi sumber daya manusia agar menjadi kreatif dan inovatif (Gaol, 2014).

Seiring dengan persaingan yang semakin tajam karena perubahan teknologi yang cepat dan lingkungan yang begitu drastis pada setiap aspek kehidupan manusia, setiap organisasi membutuhkan sumber daya manusia yang mempunyai kompetensi agar dapat memberikan pelayanan yang prima dan bernilai. Dengan kata lain, organisasi tidak hanya mampu memberikan pelayanan yang memuaskan (kostumer satisfaction), tetapi juga berorientasi pada nilai (costumer value) sehingga organisasi tidak sematamata mengejar pencapaian produktivitas kerja yang tinggi, tetapi lebih kepada kinerja dalam proses pencapaiannya (Gaol, 2014).

Gaya kepemimpinan transformasional menurut (Mondiani, 2014) adalah kemampuan untuk memberikan inspirasi dan memotivasi para pengikutnya untuk mencapai hasil-hasil yang lebih besar daripada yang direncanakan secara orisinil dn untuk imbalan internal. Selain kepemimpinan transformasional pihak perusahan harus memberikan kesejahteraan atas apa yang telah diberikan karyawan kepada perusahaan. Kompensasi adalah segala sesuatu yang diberikan perusahaan kepada karyawan sebagai balas jasa atas kontribusi yang diberikan dari karyawan kepada perusahaan. (Mulyadi, 2015) 
Setiap perusahaan tentunya ingin memiliki karyawan dengan tanggung jawab yang penuh terhadap tugas yang di perintahkan. Maka dari itu menurut Edison (2016:190) kinerja adalah suatu proses yang mengacu dan di ukur selama periode waktu tertentu berdasarkan ketentuan atau kesepakatan yang telah ditetapkan sebelumnya. Prawirosentono dalam sinambela (2016:48) kinerja adalah hasil kerja yang dapat dicapai oleh seseorang atau kelompok orang dalam suatu organisasi, sesuai dengan wewenang dan tanggung jawab masing-masing, dalam upaya pencapaian tujuan organisasi bersangkutan secara legal, tidak melanggar hokum dan tidak bertentangan dengan moral dan etika.

Setiap perusahaan tentunya ingin memiliki pemimpin yang dapat memotivasi para karyawannya dan pemimpin yang adil atas balas jasa yang diberikan oleh karyawannya. Terdapat dua pembahasan yang penting dalam penelitian ini yaitu kepemimpinan transformasional dan kompensasi finansial. Kedua pembahasan tersebut mampu meningkatkan kinerja karyawan dengan memberikan motivasi dan standar kerja yang benar mengenai apa yang harus dilakukan oleh para karyawan, begitu pula dengan perusahaan yang merupakan objek penelitian yang digunakan oleh penulis.

Perusahaan yang akan saya teliti adalah perusahaan instalasi pengolahan air minum yang mengolah air baku yang bersumber dari sungai Cisadane menjadi air minum yang memenuhi persyaratan 3K (Kualitas, Kuantitas dan Kontibuitas). Kualitas air minum mengacu pada standar Permenkes No.492/MENKES/PER/IV/2010 dan standar kinerja PDAM Tirta Kerta Rahaja. Sumber air baku yang di olah adalah Sungai Cisadane, Air Minum yang dihasilkan digunakan oleh penduduk Tangerang Selatan, Jakarta Selatan dan Jakarta Barat. Penduduk yang dilayani oleh perusahaan tersebut sudah lebih dari 1 juta orang. Rasa saling percaya dan saling perhatian antar pemimpin maupun rekan kerja perusahaan membuat para karyawan bekerja dengan rasa tanggung jawab yang baik terhadap individu dan lingkungan kerja. serta pada saat karyawan melaksanakan tugasnya masing-masing para karyawan mendapatkan kenyamanan bekerja, sehingga dapat meningkatkan kualitas kerja yang baik.

Pada perusahaan tersebut setiap karyawan selalu disiplin pada saat melakukan segala sesuatu yang bersangkutan dengan tugas pekerjaan yang diberikan. Sehingga dari uraian latar belakang ini penulis ingin melakukan penelitian dengan judul "Pengaruh Gaya Kepemimpinan dan Kompensasi Finansial Terhadap Kinerja Karyawan”.

Berdasarkan fenomena yang terjadi dalam meningkatkan kinerja karyawan, maka didapatkan masalah yang dirumuskan sebagai berikut:

1. Apakah gaya kepemimpinan transformasional berpengaruh terhadap kinerja karyawan PT Traya Tirta Cisadane?

2. Apakah kompensasi finansial berpengaruh terhadap kinerja karyawan PT Traya Tirta Cisadane?

Dari perumusan masalah diatas, maka tujuan penelitian ini adalah mengetahui gaya kepemimpinan transformasional dan kompensasi finansial terhadap kinerja karyawan yang akan dibahas pada penelitian ini dengan PT Traya Tirta Cisadane sebagai objek penelitian.

\section{LANDASAN TEORI}

\section{Gaya Kepemimpinan Transformasional}


Menurut Robbins dan Judge (2015) Kepemimpinan transformasional adalah pemimpin yang menginspirasi para pengikutnya untuk menyampingkan kepentingan pribadi mereka demi kebaikan organisasi dan mereka mampu memiliki pengaruh yang luar biasa pada diri para pengikutnya. Mereka menaruh perhatian terhadap kebutuhan pengembangan diri para pengikutnya, mengubah kesadaran para pengikut atas isu-isu yang ada dengan cara membantu orang lain memandang masalah lama dengan cara yang baru, serta mampu menyenangkan hati dan menginspirasi para pengikutnya untuk bekerja keras guna mencapai tujuan-tujuan bersama.

Berdasarkan teori diatas dapat disimpulkan bahwa gaya kepemimpinan transformasional adalah pemimpin yang mampu menginspirasi dan memberikan motivasi terhadap para pengikutnya untuk mengutamakan tujuan organiasasi.

\section{Indikator:}

- kemampuan mengambil keputusan

- kemampuan memotivasi karyawan,

- kemampuan komunikasi

- kemampuan mengendalikan bawahan, tanggung jawab

- kemampuan mengendallikan emosional.

\section{Kompensasi Finansial}

Kompensasi finansial adalah sesuatu yang diterima oleh karyawan dalam bentuk gaji, bonus, upah, asuransi dan lain-lain yang dibayar oleh organisasi (Dessy, 2015)

\section{Indikator:}

Kompensasi terbagi menjadi dua bagian, yaitu kompensasi finansial secara langsung dan kompensasi finansial secara tidak langsung.

- kompensasi finansial secara langsung meliputi bayaran yang diperoleh seseorang dalam bentuk insentif, gaji dan bonus.

- Sedangkan kompensasi finansial secara tidak langsung yaitu program asuransi, ruang kantor, serta pemberian fasilitas seperti kendaraan.

Berdasarkan penjelasan diatas menurut penulis bahwa kompensasi finansial adalah suatu imbalan yang diberikan perusahaan terhadap karyawannya dalam bentuk uang atau jasa yang mereka sumbangkan pada perusahaan.

\section{Kinerja}

Kinerja adalah hasil kerja yang dicapai oleh seorang karyawan dalam melaksanakan pekerjaannya sesuai dengan standar kinerja yang telah ditetapkan oleh perusahaan tersebut (Mamik;2010, Apriyanto:2015). Kinerja merupakan suatu kondisi yang harus diketahui dan dikonfirmasikan kepada pihak tertentu untuk mengetahui tingkat pencapaian hasil suatu instansi dihubungkan dengan visi yang diemban suatu organisasi atau perusahaan serta mengetahui dampak positif dan negatif dari suatu kebijakan operasional. (Edison, 2018)

\section{Dimensi dan Indikator}

Dimensi yang dipakai sebagai panduan dalam penelitian ini adalah kinerja seperti (Robbins, 2014) yaitu:

1. Kuantitas 
Kuantitas merupakan jumlah yang dinyatakan dannyang dihasilkan seperti jumlah, unit, jumlah siklus aktivitas yang diselesaikan.

2. Kualitas

Kualitas merupakan tingkat baik buruknya persepsi karyawan terhadap kualitas pekerjaan yang dihasilkan oleh karyawan tersebut.

3. Efektivitas

Merupakan tingkat penggunaan sumber daya organisasi (tenaga, teknologi, uang serta bahan baku) dimaksimalkan dengan maksud menaikkan hasil dari setiap unit penggunaan sumber daya.

4. Kemandirian

Merupakan tingkatan dari seorang karyawan yang nantinya akan dapat menjalakan fungsi kerjanya

Kinerja seseorang dapat diukur berdasarkan tiga dengan memenuhi target, kualitas, dan tepat waktu dalam penyelesaian tugasnya harus dilakukan dengan cara yang benar dan tepat juga, transparan dan juga dapat dipertanggung jawabkan. Menurut (setiawan, 2014) untuk menentukan tingkat inerja dapat menggunakan indikator-indikator sebagai berikut:

1. Ketepatan penyelesaian tugas

Dalam hal ini dapat dilihat bagaimana karyawan dapat mengelola waktu yang dimiliki dengan menyelesaikan pekerjaannya dengan tepat waktu.

2. Kesesuaian jam kerja

Karyawan mematuhi semua peraturan perusahaan yang dimana bersangkutan dengan ketepatan kehadiran pada waktu masuk atau pulang kerja dan juga jumlah kehadiran.

3. Tingkat kehadiran

Dalam periode tertentu dihitung jumlah ketidak hadiran karyawan

4. Kerja sama antar karyawan

Setiap karyawan mampu dalam bekerja sama dengan karyawan lainnya guna untuk mencapai tujuan perusahaan dan juga dapat menyelesaikan tugasnya dengan baik.

5. Kepuasan kerja

\section{Kerangka Penelitian}




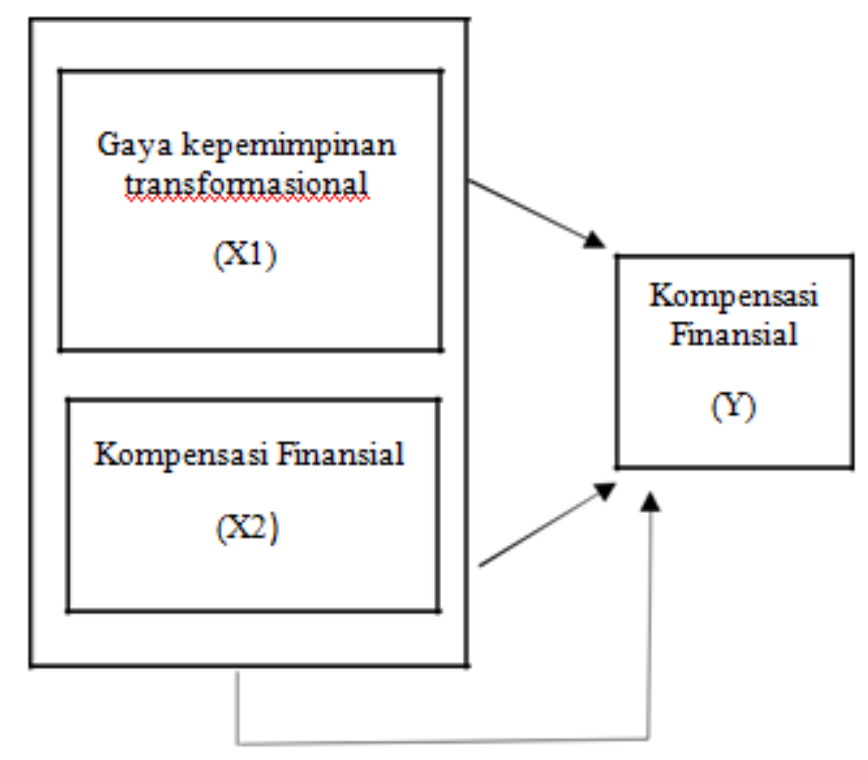

\section{Hipotesis}

Berdasarkan penelitian sebelumnya yang berjudul pengaruh Kepemimpinan Transformasional dan Kompensasi Finansial terhadap Kepuasan Kerja dan Kinerja Karyawan Departemen Collection Pada Perusahaan Finance Di Bali pada Tahun 2015, terdapat pengaruh signifikan antara pengaruh gaya kepemimpinan transformasional dan kompensasi finansial terhadap kinerja karyawan maka dapat disimpulkan sebagai berikut:

H1: Terdapat pengaruh antara Gaya Kepemimpinan Transformasional (X1) terhadap Kinerja Karyawan (Y) di PT Traya Tirta Cisadane Serpong Tangerang Selatan

H2: Terdapat pengaruh antara Kompensasi Finansial (X2) terhadap Kinerja Karyawan (Y) di PT Traya Tirta Cisadane Serpong Tnagerang Selatan

H3: Terdapat pengaruh antara Gaya Kepemimpinan Transformasional (X1) dan Kompensasi Finansial (X2) terhadap Kinerja Karyawan (Y) di PT Traya Tirta Cisadane Serpong Tangerang Selatan. Setiap karyawan merasa puas akan pekerjaan yang diberikan kepadanya yang sudah menjadi tanggung jawab untuk kedepannya.

\section{METODE PENELITIAN}

Metode penelitian ini menggunakan metode penelitian kualitatif. Sumber data ini berasal dari sumber sekunder, yaitu studi pustaka. Teknik dalam pengambilan data yang digunakan dalam penulisan makalah ini adalah literature review. Data yang didapatkan akan dianalisis dengan merujuk pada teknik analisis data kualitatif, dengan cara reduksi data, sajian data, dan penarikan kesimpulan (Yuliansyah, Hakim, dan Suryani, 2015). Objek penelitian dari penelitian ini adalah karyawan perusahaan. Variable independen dalam penelitian ini adalah gaya kepemimpinan transformasional (X1), kompensasi finansial (X2), dan variable independen dalam penelitian ini adalah kinerja karyawan PT Traya Tirta Cisadane (Y).

\section{HASIL DAN PEMBAHASAN}


Berdasarakan penelitian dari jurnal sebelumnya yaitu jurnal dengan judul "Pengaruh Gaya Kepemimpinan Transformasional dan Kompensasi terhadap Kepuasan Kerja dan Kinerja Karyawan Departemen Collection pada Perusahaan Finance Bali ditemukan bahwa Kepemimpinan transformasional dan kompensasi berpengaruh positif secara langsung terhadap kepuasan kerja dan kinerja karyawan. Kepuasan kerja berpengaruh positif secara langsung terhadap kinerja karyawan. Kepemimpinan transformasional dan kompensasi berpengaruh positif secara tidak langsung terhadap kepuasan dan kinerja karyawan.

Namun pada jurnal yang berjudul "Pengaruh Gaya Kepemimpinan Transformasional dan Kompensasi Finansial terhadap Kinerja Karyawan" ditemukan bahwa terdapat pengaruh yang signifikan antara kepemimpinan transformasional, namun ditemukan bahwa terdapat pengaruh yang tidak signifikan antara kompensasi secara tidak langsung terhadap kinerja karyawan.

\section{KESIMPULAN}

Berdasarkan hasil penelitian yang didapatkan, dapat disimpulkan bahwa gaya kepemimpinan transformasional dan kompensasi finansial berpengaruh signifikan atau positif terhadap kinerja karyawan, seperti pemimpin mampu menjadi motivasi atau contoh bagi karyawannya untuk bekerja lebih semangat lagi, dan pemimpin dapat memberikan perhatian kepadakaryawan secara individu dan pemimpin bertanggung jawab atas apa yang sudah diberikan oleh karyawan terhadap perusahaan

Maka saran untuk peneliti selanjutnya, jika ingin menelitikepemimpina transformasional dan kompensasi dapat menggunakan X dan Y saja. Namun jika inginmeneliti gaya kepemimpinan transformasional, kompensasi finansial dan kinerja karyawan secara keseluruhan maka sebaiknya digunakan X, Y dan Z.

\section{DAFTAR PUSTAKA}

Apriyanto, W., \& Satrio, R. B. (2015). Pengaruh Gaya Kepemimpinan Transformasional dan Motivasi Kerja Terhadap Kinerja Karyawan. Jurnal Ilmu dan Riset Manajemen (JIRM), 4(11).

C.J, G. (2014). Human Kapital: Sumber daya manusia. jakarta: Grasindo.

Dessy, P. W. (2015). pengaruh gaya kepemipinan transformasional dan kompensasifinansial terhadap kinerja karyawan .Erlangga.

Edison, E., Anwar, Y., \& Komariyah, I. 2016. Manajemen Sumber Daya Manusia. (Cetakan kesatu).Bandung: Alfabeta.

Jimmy, G. (2015). A to Z Human Capital Manajemen Sumber Daya Manusia. Grasindo. Jakarta.

Mondiani, T. (2012). Pengaruh kepemimpinan transformasional dan kompensasi terhadap kinerja karyawan PT. PLN (PERSERO) UPJ Semarang. Jurnal Administrasi 
Bisnis, 1(1), 46-54.

Kusumah, M. (2016). Pengaruh kompensasi kepemimpinan terhadap kepuasan karyawan dan implikasinya terhadap kinerja karyawan (Studi Terhadap Karyawan Penunjang Medis Rumah Sakit Al Islam Bandung) (Doctoral dissertation, UNPAS).

Robbins, S., \& Coulter, M. (2007). Manajemen, Edisi Kedelapan. Jakarta: PT Indeks.

Setiawan, F., \& Dewi, A. S. K. (2014). Pengaruh kompensasi dan lingkungan kerja terhadap kinerja karyawan pada CV. Berkat Anugrah. E-Jurnal Manajemen, 3(5). 